\title{
Voltage Regulation in BDC Based on Fuzzy Logic Controller using Solar Power Generation
}

\author{
K. Balaji, D. Vidhyalakshmi
}

\begin{abstract}
The PhotoVoltaic (PV) based grid system coupled with Bidirectional DC-DC Converter (BDC) utilize Fuzzy Logic Controller (FLC) for increasing voltage gain and reduce the settling time of DC link voltage than conventional is presented. $B D C$ satisfied the load requirements, and control the power flow from different sources such as PV, grid, and battery. However, problems in conventional system are high Total Harmonic Distortion (THD), DC link voltage gain and settling time of capacitor voltage. The generated power is used for improving the power quality at the output of the inverter using Sliding Mode Controller (SMC). The converter and inverter operate has bidirectional performance and utilize the hybrid power generation as mentioned. The battery can act as a load based on operating modes of $B D C$ and power generation. It provides a comparative analysis of Proportional Integral (PI) and FLC method that is effectively performs harmonic reduction in BDC.
\end{abstract}

Keywords: Bidirectional Converter, Fuzzy Logic Control, Sliding Mode Control.

\section{INTRODUCTION}

In recent era population growth is increased in urban countries and also high in environmental problems. There is demand of power generation in all areas, so the generation of renewable power is increased to meet out the necessity. The hybrid power generation is more useful to satisfy the load demand [1] [2]. The photovoltaic power generation is clean power source and battery is used as both source and load. The solar power is generated and fed into the grid using bidirectional converter [3]-[5]. During day time the solar generates power and transferred to grid system. During night the absence of solar the battery is utilized for power generation and transfer to grid [6]. Increasing the utilization of bidirectional converter such as electric vehicle, house hold and grid application. In conventional converter utilize transformer to perform bidirectional action and also it performs both step up and step down voltage [7]. The converter has more switches which increase the cost and the switching losses. In fly back converter used to attain high voltage step ratios but they require a transformer to enhance the voltage gain [8]-[10]. This converter has high complexity

Revised Manuscript Received on December 30, 2019.

* Correspondence Author

Dr. K. Balaji, Associate Professor, Department of Electrical and Electronics Engineering, St Peter's Institute of Higher Education and Research, Avadi, Chennai. India Email: balajiphd12@gmail.com

D. Vidhyalakshmi, Research Scholar, Department of Electrical and Electronics Engineering, St Peter's Institute of Higher Education and Research, Avadi, Chennai. India. Email: vidhyaphd05@gmail.com

(C) The Authors. Published by Blue Eyes Intelligence Engineering and Sciences Publication (BEIESP). This is an open access article under the CC BY-NC-ND license (http://creativecommons.org/licenses/by-nc-nd/4.0/) and less efficiency of this device. The battery is used has a source when solar is not available and also store the power from grid when reverse direction operates. The BDC used as important in electric vehicle application [11]-[14]. The works of this converter as both buck and boost operation. In forward direction the converter boost/step-up the voltage and in reverse direction the buck/step-down operation is performed The controller used in bidirectional converter is PI and its settling time is high [15] [16]. The pulse width modulation is implemented in three phase inverter and converts the DC to $\mathrm{AC}$ and the power is transferred to load. In conventional the Model Predictive Controller (MPC) used to regulates the inverter current and the THD is high compared to sliding mode controller (SMC). The grid connected BDC transferred the power from source to load [17]-[19]. The presented topology takes on the BDC based on grid system. The foremost objective is to maintain and reduce the dc link voltage and settling time of DC link, harmonic distortion using FLC control method. PV and battery used as a source when forward direction of BDC and grid used as source when $\mathrm{BDC}$ is reverse power flow. When PV, battery and grid are available, battery power is used for some other application. FLC is to enhance the voltage gain and also decrease the dc link voltage settling time. The sliding mode controller is designed for reducing the harmonic distortion in inverter.

\section{PROPOSED SYSTEM AND MATERIALS USED}

In proposed method decreases the settling time of dc link voltage and improve the voltage gain of the system using FLC. Fig. 1 shows the methodology of proposed grid connected system.

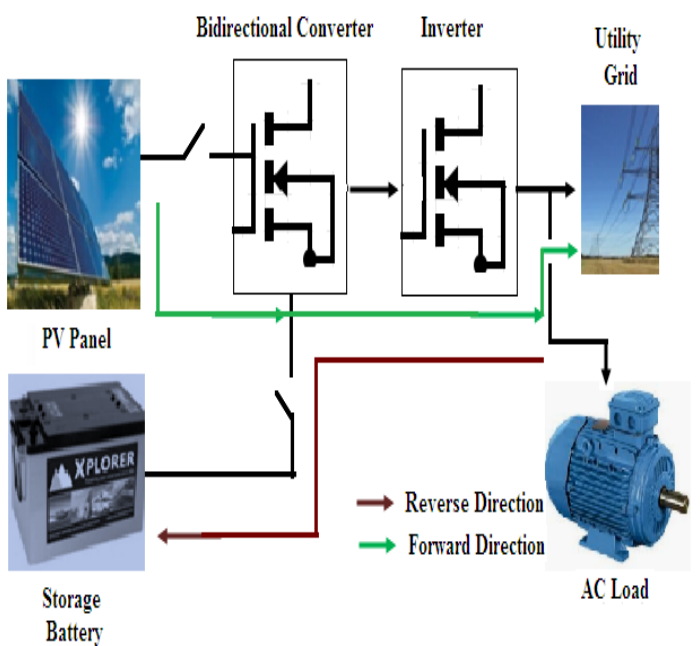

Fig. 1.Methodology of Proposed Grid Connected System

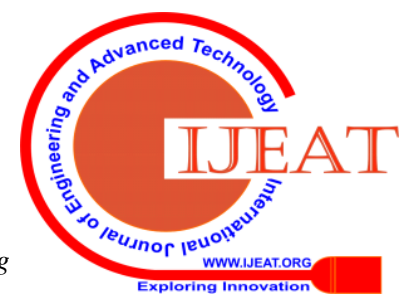




\section{A. Photovoltaic Power Generation}

The modelling of two diodes PV is to produce the characteristics of PV and VI curve by varying the irradiation and series resistance value. The PV is a passive capacitive filter which decouples the input voltage and current from power by decreasing the current and voltage ripples. The utilization of power electronic devices is increased such as UPS, power converter, air conditioner; regulator etc connected to the point of coupling the non-linearity. The non-linearity load leads to increase the harmonics present in the system and it enhance the losses. It will affect the load, heating effect of transformer and shunt capacitor. Fig. 2 shows the equivalent circuit of PV model.

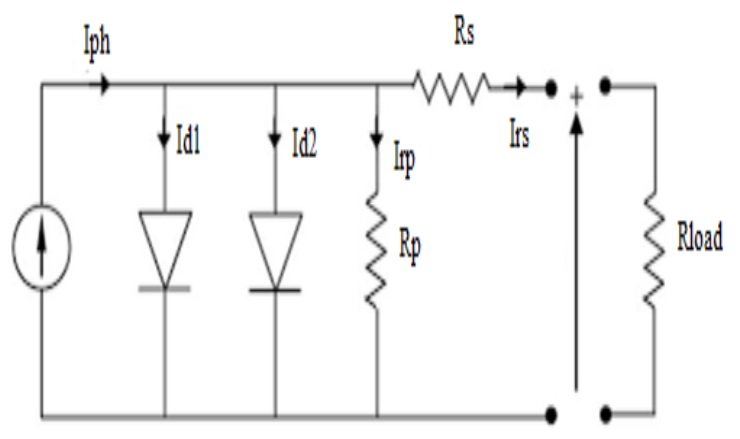

Fig. 2. Two diode PV cell equivalent circuit

The non ideal single diode and two diode of PV cell are expressed in below equation,

$$
\begin{gathered}
I=I_{\text {photo }}-I_{\text {se }}\left(\exp \frac{V+R_{s e} I}{V_{t}}-1\right)-\frac{V+R_{s e} I}{R_{s h}} \\
I=I_{\text {Photo }}-I_{D 1}-I_{D 2}-I_{\text {sh }} \\
I_{\text {Photo }}=I_{\text {ShrtCrt }}+K_{I}\left(T_{\text {Cell }}-T_{\text {ref }}\right) G \\
I_{D 1}=I_{01}\left[e^{\left(\frac{V+I R_{S}}{\alpha_{1} V_{T}}\right)}-1\right] \\
I_{D 2}=I_{02}\left[e^{\left(\frac{V+I R_{S}}{\alpha_{2} V_{T}}\right)}-1\right] \\
\left.I_{S h}=\frac{V+I R_{S}}{R_{p}}\right]
\end{gathered}
$$

The harmonics is eliminated by using shunt active filter connected to inverter. In solar power system the photo energy is greater than band gap, the photo current is proportional to the solar radiation. The two diode PV cell has more accurate characteristics under intermittent energy resource. Power electronics converters are connected at load side to maintain the voltage and current, and also used to control the power flow in grid power system.

\section{B. Bidirectional Converter}

The BDC act as buck boost converter and operates in both forward and reverse direction based on the switching configuration and it circuit diagram represent in fig. 3. The switching configuration is based on the switch and utilizes the fuzzy controller for voltage control across the output of bidirectional converter. The application of bidirectional are industrial application, electric vehicle, auxiliary system and in battery charging/discharging converters in UPS. In forward conduction mode photovoltaic or battery is used as a source and generated power fed to bidirectional converter. It works as boost converter and fed to three phase inverter.

In reverse conduction mode the grid used as a source and generate power transferred to battery. The three phase inverter operate has rectifier and converter act as buck converter and power transferred to battery. In battery the state of charge has increased and battery is charging and used for further application.

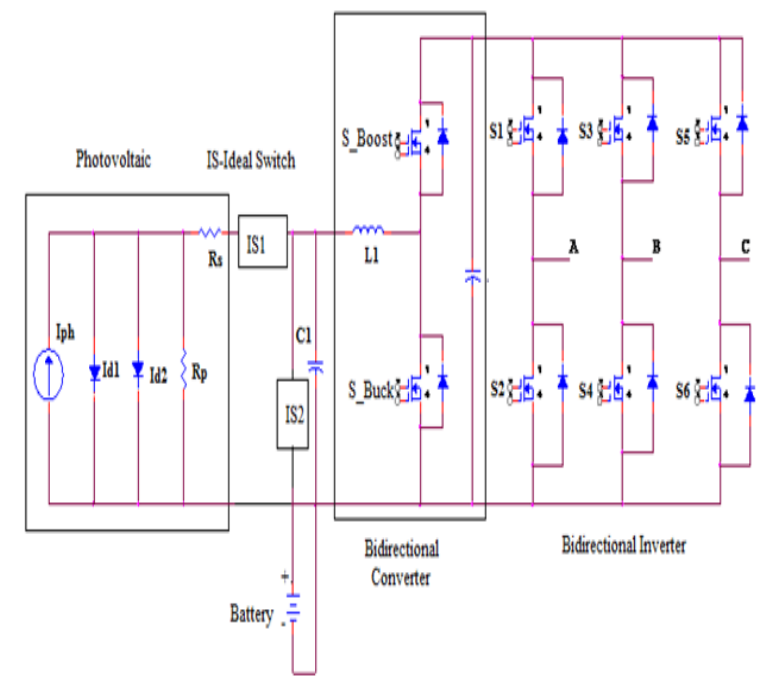

Fig. 3. Proposed Circuit diagram of bidirectional converter fed grid connected system

\section{METHODS OF CONTROL SYSTEM}

In proposed grid connected photovoltaic based converter utilized the FLC. The sliding mode control involved in inverter for improves the efficiency of the presented system. The characteristic of fuzzy control is easy to evaluate by using the optimization method.

\section{A. Fuzzy Logic Controller}

The fuzzy logic controller is implemented for dc voltage regulation at the converter output. The error and change in error is the two input of fuzzy and the output is designed by the Membership Function (MF) and centroid method is used. Process of FLC is representing in fig 4 and it contains FU, DMU, and DU. The membership function of FLC is shown in Fig. 5, 6 and 7. 


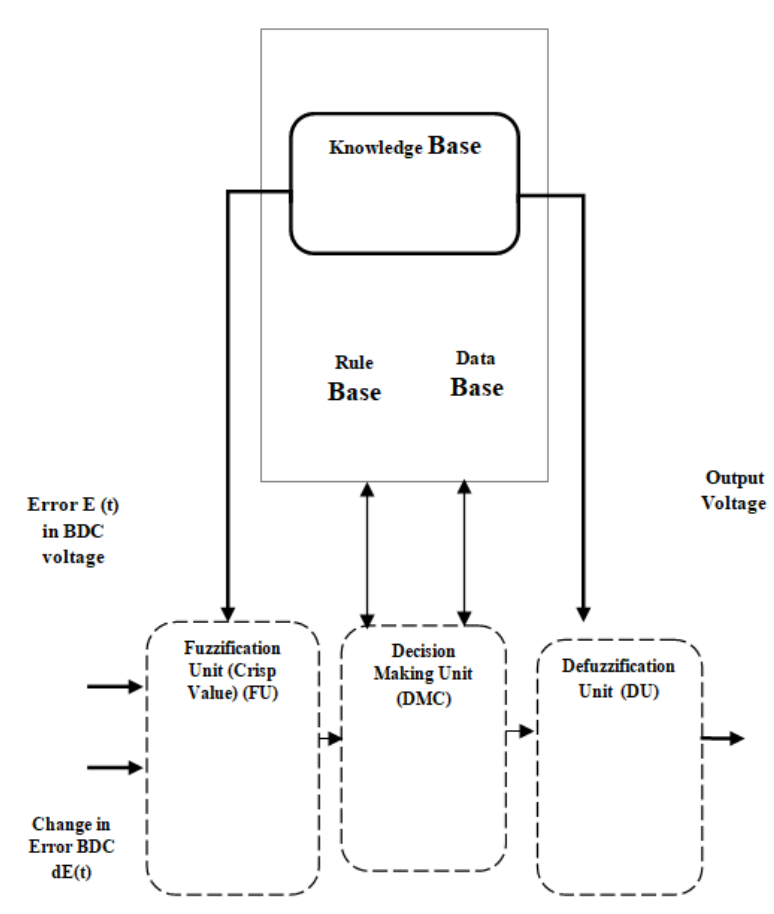

Fig. 4.Block diagram of FLC controller

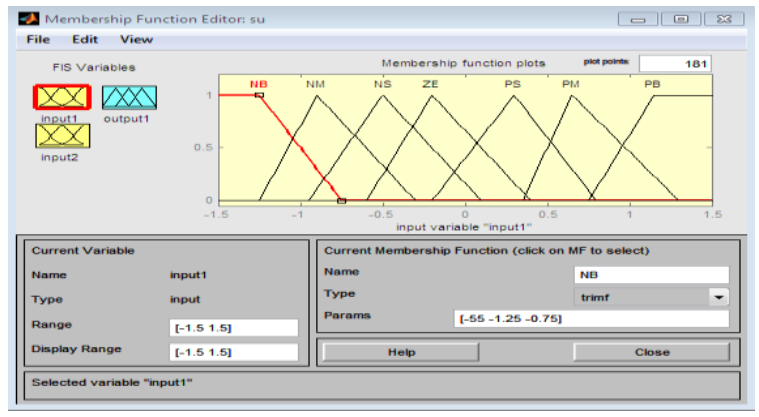

Fig. 5.Membership Function (MF) of input 1

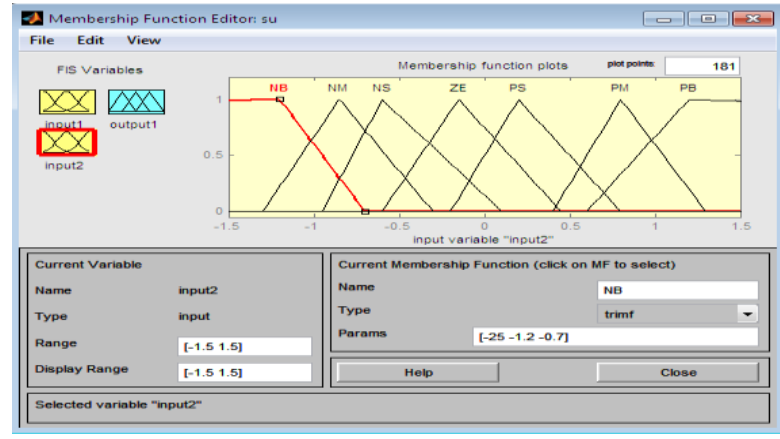

Fig. 6.Membership Function (MF) of input 2

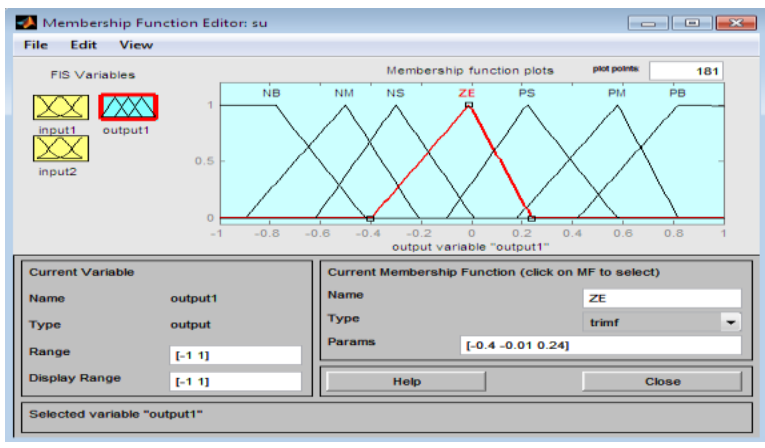

Fig. 7.FLC output
The FLC is linguistic variables use MF and rules and it process the input and generate the output. This control method is faster and simple control method.

\section{B. Sliding Mode Controller}

In SMC utilized in grid connected inverter for reducing the THD in inverter current. The error input is calculated from the differences of inverter output voltage $\left(V_{O}\right)$ and reference voltage ( $V_{\text {ref }}$ ). The block diagram of sliding mode controller is shown in Fig. 8. SMC decreases the steady state error $\left(E_{S}\right)$ because the converter maintained the stable frequency. The controller increase the capability of system order reduction and on off power semiconductors, and robustness. $E_{S}$

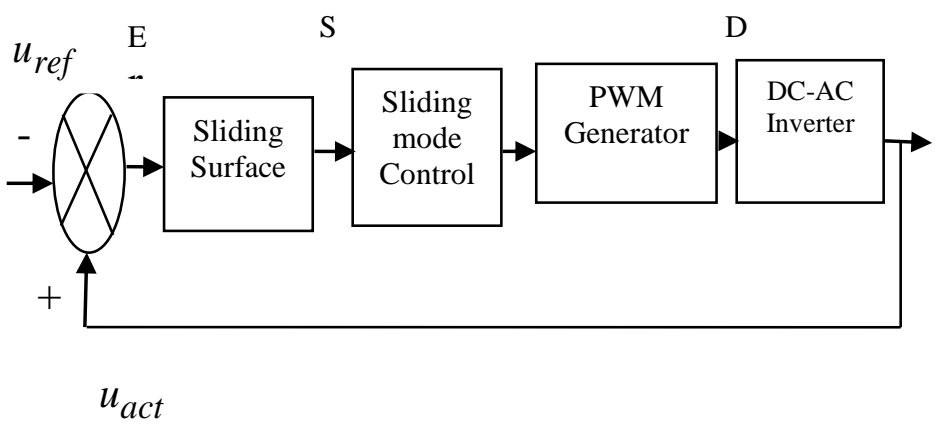

Fig. 8.Block Diagram of Sliding Mode Controller

The sliding surface $\mathrm{S}$ is chosen is given in equation.

$$
\begin{aligned}
& \text { Error }=u_{a c t}-u_{r e f} \\
& S=C \cdot \text { Error }+ \text { Error }
\end{aligned}
$$

Where $\mathrm{C}$ is a positive constant, Error is the tracking voltage of inverter output, Error is the derivative of Error. The sliding mode controller has generate the duty cycle is given in equation.

$D=\frac{1}{2}\left[1+\frac{L_{a c} C_{a c}}{u_{d c}}\left(\stackrel{\bullet}{u_{r e f}}+\frac{\bullet}{R_{a c t} C_{a c}}+\frac{u_{a c t}}{L_{a c} C_{a c}}-C\right.\right.$ Error $\left.\left.-K S\right)\right]$

Where $\mathrm{K}$ is positive constant.

\section{SIMULATION RESULTS}

The comparison of fuzzy control in bidirectional converter fed grid system for photovoltaic power generation is simulated using MATLAB/Simulink. The Simulink platform is used for modeling, simulating and analyzing the performance of proposed grid based BDC system. The control scheme of fuzzy and SMC is used to improve the efficiency in a grid connected bidirectional converter and inverter. The simulation results are validated and presented according to the following measurements: THD and voltage regulation. The overall circuit configuration of simulation block represent in Fig. 9. Fig. 10 shows the Simulink Model of SMC.

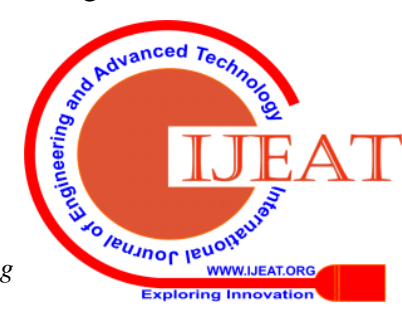




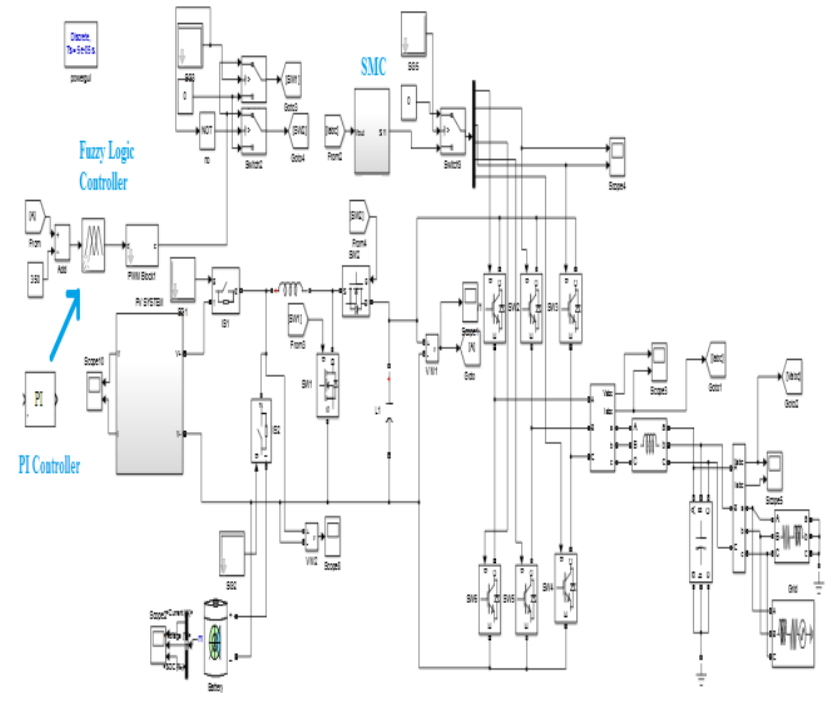

Fig. 9.Simulink Model of Overall Grid Connected Bidirectional Converter

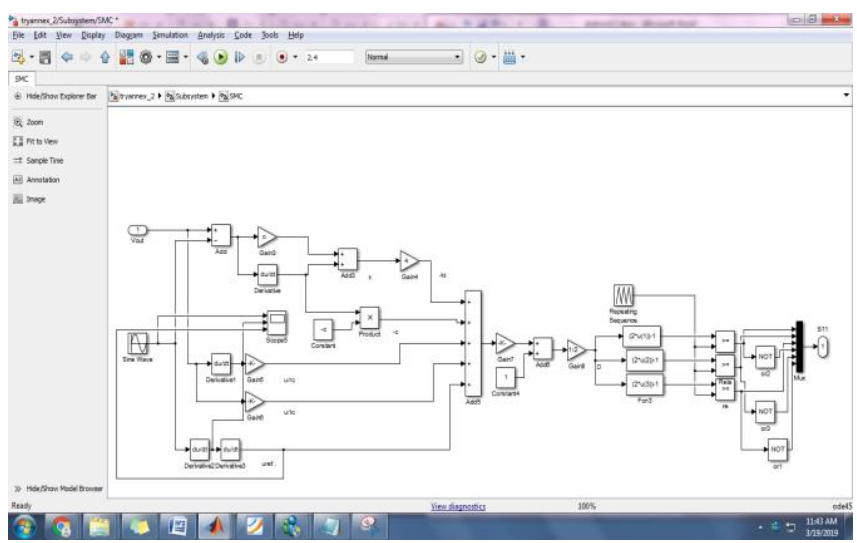

Fig. 10. Simulink Model of Sliding Mode Controller

The DC link voltage of BDC using fuzzy control is shown in Fig. 11. The output voltage and current of the bidirectional inverter is shown in Fig. 12. The total harmonic distortion of grid connected inverter using fuzzy has shown in Fig. 13. Table 2 represents the comparison of DC link voltage and \%THD values PI and fuzzy control. The simulation parameters are given in table I. Table II gives the comparison \%value of THD using PI and fuzzy control.

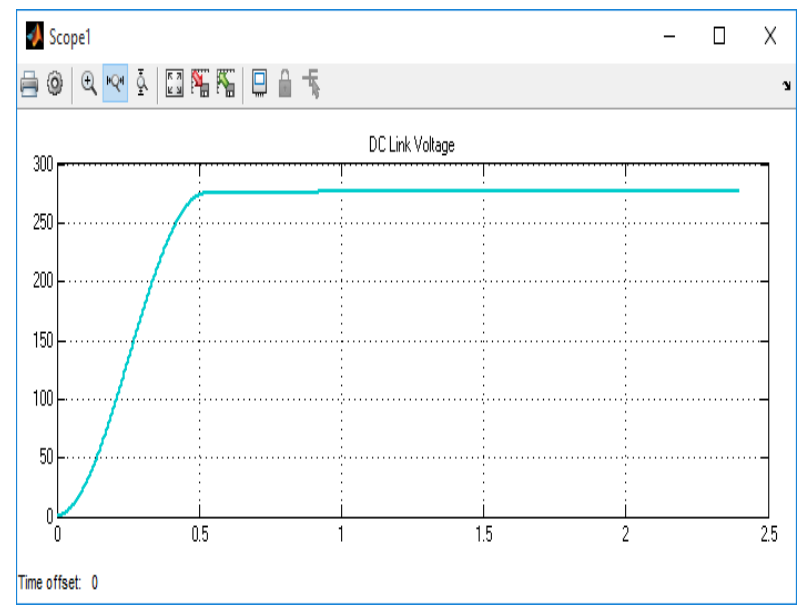

Fig. 11. DC Link Voltage of Bidirectional Converter System using FLC

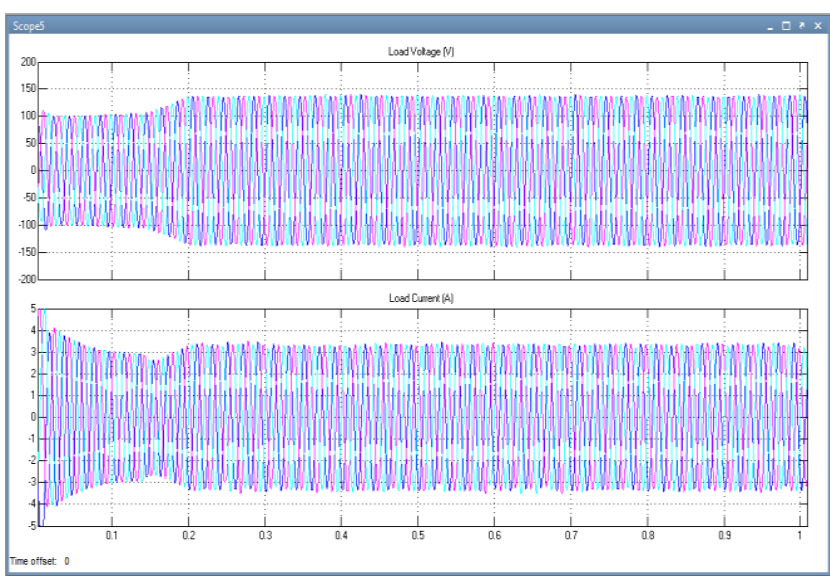

Fig. 12. Three Phase Voltage and Current waveform across Grid System

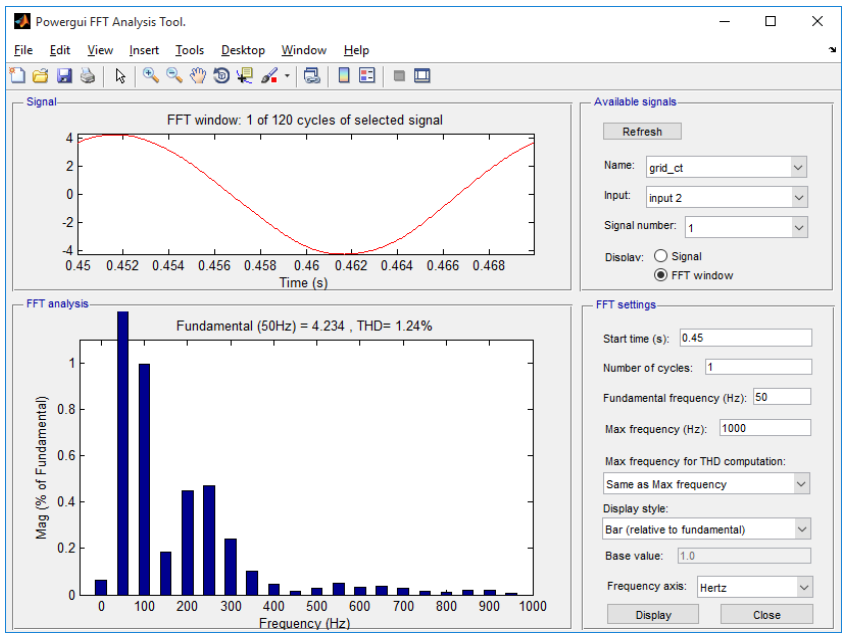

Fig. 13. Total Harmonic distortion in Grid current using FLC

Table- I: Simulation Parameter

\begin{tabular}{|c|c|}
\hline Parameter & Value \\
\hline Solar Voltage (V) & $110 \mathrm{~V}$ \\
\hline $\begin{array}{c}\text { Battery Capacity and } \\
\text { Voltage }\end{array}$ & $110 \mathrm{~V}$ \\
\hline Switching Frequency & $5000 \mathrm{~Hz}$ \\
\hline Bidirectional Inductor & $5 \mathrm{mH}$ \\
\hline Bidirectional Capacitor & $130 \mathrm{mF}$ \\
\hline Inductive Filter & $47 \mathrm{mH}$ \\
\hline Capacitive Filter & $80 \mathrm{e}-6 \mathrm{~F}$ \\
\hline
\end{tabular}

Table- II: DC link, \%THD of PI Control and Fuzzy

\begin{tabular}{|c|c|c|}
\hline Parameter & $\begin{array}{c}\text { DC Link } \\
\text { Voltage } \\
\text { (V) }\end{array}$ & $\begin{array}{c}\text { THD } \\
\text { (\%) }\end{array}$ \\
\hline PI & 160 & 1.47 \\
\hline Fuzzy & 280 & 1.24 \\
\hline
\end{tabular}

\section{CONCLUSION}

The hybrid energy generation system based on bidirectional converters are utilized FLC control for voltage improvement, reduce the settling time and reduce the total harmonic distortion.

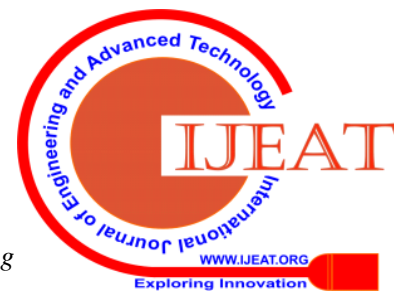


The solar and battery used to extract the maximum power using FLC and fed to bidirectional converter followed by bidirectional inverter. The control methods of converter have fuzzy control for voltage regulation and enhance the voltage gain. The sliding mode controller is utilized in bidirectional inverter for decrease the THD. The proposed BDC fed grid method is operated in both forward and reverse power and it is verified in simulation results.

\section{REFERENCES}

1. B. Aamir, S. Mekhilef and H.J. Kim, "High-gain zero-voltage switching bidirectional converter with a reduced number of switches", IEEE Transactions on Circuits and Systems II: Express Briefs, vol. 62, no. 8, pp.816-820, 2015.

2. B. Mangu, S. Akshatha, D. Suryanarayana and B.G. Fernandes, "Grid-connected pv-wind-battery-based multi-input transformer-coupled bidirectional dc-dc converter for household applications", IEEE journal of emerging and selected topics in power electronics, vol. 4, no. 3, pp.1086-1095, 2016.

3. Y.S. Lee, Y.P. Ko, M.W. Cheng and L.J. Liu, "Multiphase zero-current switching bidirectional converters and battery energy storage application", IEEE Transactions on Power Electronics, vol. 28, no. 8, pp.3806-3815, 2013.

4. Y.B. Koca, Y. Oğuz and A. Yönetken, "Investigation efficiency and microcontroller-based energy flow control for wind-solar-fuel cell hybrid energy generation system with battery storage." Measurement and Control, vol. 50, no. 7-8, pp.159-168, 2015.

5. V.F. Pires, D. Foito and A. Cordeiro, "A DC-DC Converter with Quadratic Gain and Bidirectional Capability for Batteries/Super capacitors", IEEE Transactions on Industry Applications, vol. 54, no. 1, pp.274-285, 2018.

6. Y. Zhang, X.F. Cheng, C. Yin and S. Cheng, "Analysis and Research of a Soft-Switching Bidirectional DC-DC Converter without Auxiliary Switches", IEEE Transactions on Industrial Electronics, vol. 65, no.2, pp.1196-1204, 2018.

7. H. Jeong, M. Kwon and S. Choi, "Analysis, Design, and Implementation of a High Gain Soft-Switching Bidirectional DC-DC Converter with PPS Control", IEEE Transactions on Power Electronics, vol. 33, no. 6, pp.4807-4816, 2018.

8. K. Balaji, "Improved Voltage gain by the implementation of Soft Switching technique in flyback converter", International Research Journal of Engineering and Technology, vol. 3, no. 8, pp. 1911-1914, 2018.

9. R. Ranihemamalini and K. Rathnakumar D.Jayahar, "Design and implementation of hysteresis current mode controller for buck boost converter for power factor correction and harmonic elimination", Middle East Journal of Scientific Research, pp. 18-26, 2015.

10. M. Kwon and S. Choi, "Control scheme for autonomous and seamless mode switching of bidirectional DC-DC converters in a DC microgrid", IEEE Trans. Power Electron, 2017.

11. V. Karthikeyan and R. Gupta, "Multiple-Input Configuration of Isolated Bidirectional DC-DC Converter for Power Flow Control in Combinational Battery Storage", IEEE Transactions on Industrial Informatics, vol. 14, no. 1, pp.2-11, 2018.

12. M.W. Beraki, J.P.F. Trovão, M.S. Perdigão and M.R. Dubois, "Variable Inductor Based Bidirectional DC-DC Converter for Electric Vehicles", IEEE Transactions on Vehicular Technology, vol. 66, no. 10, pp.8764-8772, 2017.

13. A.M. Florez-Tapia, J. Vadillo and J.M. Echeverria, "Fault tolerance of the bidirectional trans-quasi-Z-source inverter", International Journal of Electrical Power \& Energy Systems, vol. 95, pp.440-450, 2018.

14. S. Hu, Z. Liang and X. He, "Ultra-capacitor-battery hybrid energy storage system based on the asymmetric bidirectional Z-source topology for EV', IEEE Transactions on Power Electronics, vol. 31, no. 11, pp.7489-7498, 2016.

15. S.M. Dehghan, M. Mohamadian and A. Yazdian, "Hybrid electric vehicle based on bidirectional Z-source nine-switch inverter", IEEE Transactions on Vehicular Technology, vol. 59, no. 6, pp.2641-2653, 2010.

16. G. Swaminathan, V. Ramesh, S. Umashankar, and P. Sanjeevikumar, "Investigations of microgrid stability and optimum power sharing using robust control of grid tie pv inverter", In Advances in Smart Grid and Renewable Energy, pp. 379-387.Springer, Singapore, 2018.

17. V. Vasudevan and K. Balaji, "Modeling and Dynamic Performance of Photovoltaic and Fuel Cell Power Generation for Hybrid Converter System”, Medico-Legal Update, vol. 18, no.1, 2018.
18. R. Ranihemamalini and K. Rathnakumar D.Jayahar, "Design and implementation of hysteresis current mode controller for buck boost converter for power factor correction and harmonic elimination", Middle East Journal of Scientific Research, pp. 18-26, 2015.

19. X. Pan, A. Ghoshal, Y. Liu, Q. $\mathrm{Xu}$ and A.K. Rathore, "Hybrid-Modulation-Based Bidirectional Electrolytic Capacitor-Less Three-Phase Inverter for Fuel Cell Vehicles: Analysis, Design, and Experimental Results", IEEE Transactions on Power Electronics, vol. 33, no.5, pp.4167-4180, 2017

\section{AUTHORS PROFILE}

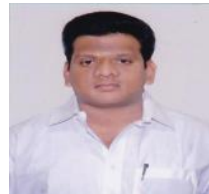

Dr. K. Balaji, has received the Bachelor degree (BE) in Electrical and Electronics Engineering from Madha Engineering College, Anna University, India in 2005, and the Master of Engineering degree (ME) in Power Electronics from St. Peter's Engineering College, Anna University, in 2009. He has obtained his Ph.D. degree from St. Peters higher education and research, Chennai. Currently he is working as a Professor and Head in St. Peters higher education and research, Chennai, Tamilnadu, India. He has published papers in National, International conferences and journals in the field of power electronics.

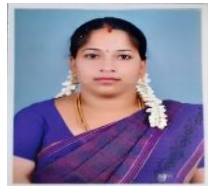

D. Vidhya lakshmi, has received the Bachelor degree(BE) in electrical and electronics engineering from Sree Sastha Institute of Science and Technology Anna University, India in 2008, the Master's degree (ME) in Power Electronics \& Drives from Madha Engineering college, Anna University, In 2010. Currently she is pursuing Doctor of Philosophy (Ph.D) in St. Peter's Institute of Higher Education and Research Avadi, Chennai, India. 